НАУКОВИЙ ВІСНИК

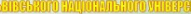

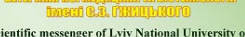

Sientific messenger of Lviv National University
Veterinary Medicine and Biotechnologites

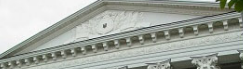

तो है है

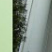

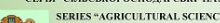

Tом 21 № 91

2019
Науковий вісник Дьвівського національного університету ветеринарної медицини та біотехнологій імені С.3. Гжицького. Серія: Сільськогосподарські науки

\author{
Scientific Messenger of Lviv National University
} of Veterinary Medicine and Biotechnologies. Series: Agricultural sciences

ISSN 2519-2698 print

https://nvlvet.com.ua/index.php/agriculture

doi: $10.32718 /$ nvlvet-a9121

UDC 661.745.

\title{
To the question of amino acids and whey consumption
}

\author{
O.O. Korytko
}

Stepan Gzhytskyi National University of Veterinary Medicine and Biotechnologies Lviv, Ukraine

Article info

Received 23.09.2019

Received in revised form 21.10 .2019

Accepted 22.10.2019

Stepan Gzhytskyi National University of Veterinary Medicine and Biotechnologies Lviv, Pekarskaya Str., 50, Lviv, 79010, Ukraine.

Tel.: +38-096-632-65-12

E-mail:biochem@lvet.edu.ua
Korytko, O.O. (2019). To the question of amino acids and whey consumption. Scientific Messenger of Lviv National University of Veterinary Medicine and Biotechnologies. Series: Agricultural sciences, 21(91), 116-122. doi: 10.32718/nvlvet-a9121

The article summarizes, in a concise form, information about the importance of amino acids in the context of solving the problem of fodder protein deficiency. Amino acids, as structural components of proteins, are central to the exchange of nitrogen-containing compounds and are vital for life processes. Essential amino acids are not synthesized by the body of animals and humans, but are prepared as a part of diets. Vegetable proteins are less complete than animal proteins due to the absence of some essential amino acids. Therefore, in feeding, plant feeds are balanced by limiting amino acids, which are obtained by chemical or microbiological synthesis, or combine protein sources, taking into account their amino acid composition. Amino acids are the primary microbial metabolites that are synthesized by microorganisms in the process of life. Due to the large-scale cultivation of microorganisms in industrial conditions, amino acids, proteins, preparations for increasing the productivity of crops and animals are receive. Appropriate types of microorganisms use ammonia oxidation energy to synthesize their own organic matter. Different bacteria for the synthesis of amino acids also use nitrogen, nitrates, urea. The microbiological synthesis and accumulation of metabolites in the substrate depends on the component composition, temperature. Microbial growth is usually limited by the nutrient component. Sulfur deficiency limits the utilization of nitrogen by microorganisms. The introduction of sulfur compounds into the environment stimulates microbial synthesis in general, including sulfur-containing amino acids. As a result of incubation of the biosubstrate for 3 days at a temperature of $18{ }^{\circ} \mathrm{C}$, the synthesis of most amino acids by microbial association was activated. Incubation with sodium sulfate (at a dose of $0.3 \%$ by weight of biosubstrate) for 3 days at $25{ }^{\circ} \mathrm{C}$ had the best stimulating effect on amino acid biosynthesis. Such a biosubstrate can be used as a source of amino acids in the form of a fertilizer or feed additive. In the XXI century anthropogenic impact causes an imbalance of the ecological situation, one of the manifestations of which is the reduction of soil fertility, which can be restored by the introduction of mineral and organic fertilizers, as well as preparations containing amino acids and stimulate seed germination, increase the yield, fertility, and fertility. Amino acids are used as additives in food production, in the treatment of diseases of different etiologies and for other purposes.

Key words: amino acids, proteins, essential amino acids, methionine, lysine, nutrients, microorganisms, microbiological synthesis, L- izomers, plants, animals, bio subtrate, surrounding, food supplements.

\section{До питання про роль амінокислот і їх застосування}

\author{
О.О. Коритко
}

Львівський національний університет ветеринарної медицини та біотехнологій імені С.3. Гжицького, м. Львів, Україна

У статті в стислій формі узагальнено відомості про значення амінокислот у контексті вирішення проблеми дефіциту кормового білка. Амінокислоти як структурні компоненти білків займають центральне місце в обміні нітрогеновмісних сполук $і$ є вітальними для життєвих процесів. Незамінні амінокислоти організм тварин і людей не синтезує, а одержує в готовому вигляді у складі раціонів. Рослинні білки мени повноцінні, ніж тваринні, через відсутність деяких незамінних амінокислот. Тому в годівлі рослинні корми балансують за лімітними амінокислотами, які одержують хімічним чи мікробіологічним синтезом, або комбіну- 
ють джерела білка з урахуванням їх амінокислотного складу. Амінокислоти - первинні мікробні метаболіти, які мікроорганізми синтезують в прочесі життєдіяльності. Завдяки маситабному вирощуванню мікроорганізмів у промислових умовах отримують амінокислоти, білки, препарати для підвищення продуктивності сільськогосподарських культур і тварин. Відповідні види мікроорганізмів під час синтезу власних органічних речовин використовують енергію окиснення амоніаку. Різні бактерії для синтезу амінокислот використовують також азот, нітрати, сечовину. Мікробіологічний синтез $і$ накопичення метаболітів у субстраті залежить від компонентного складу, температури. Мікробний ріст зазвичай лімітований за поживним компонентом. Дефіиит сульфуру лімітує утилізацію нітрогену мікроорганізмами. Внесення у середовище сполук сульфуру стимулює мікробний синтез загалом, включно із сульфуровмісними амінокислотами. В результаті проведеного нами інкубування біосубстрату протягом 3 діб при температурі $18{ }^{\circ} \mathrm{C}$ активувався синтез більшості амінокислот мікробною асочіацією. Інкубування із сульфатом натрію (в дозі 0,3\% від маси біосубстрату) протягом 3 діб при температурі $25{ }^{\circ} \mathrm{C}$ мало кращий стимулюючий вплив на біосинтез амінокислот. Такий біосубстрат можна застосувати як джерело амінокислот у формі добрива чи кормової добавки. У ХХІ ст. антропогенний вплив спричиняє дисбаланс екологічної ситуації, одним із проявів якого є зниження родючості трунту, яку можна відновити внесенням мінеральних та органічних добрив, також препаратів, щчо містять амінокислоти і стимулюють проростання насіння, підвищують врожайність, родючість трунту, стійкість рослин до дї стрес-факторів. Амінокислоти застосовують як добавки при виробництві харчових продуктів, у лікуванні захворювань різної етіології та для інших цүілей.

Ключові слова: амінокислоти, білок, метіонін, лізин, поживні речовини, рубець, середовще, біосубстрат, трунт, біопрепарати, кормові добавки.

\section{Ветуп}

У третьому тисячолітті в умовах посиленого антропогенного впливу на довкілля актуальною залишається проблема дефіциту білка. Її вирішення пов'язане $з$ підвищенням родючості грунтів та продуктивності сільськогосподарських культур, поліпшенням якості рослинних кормів шляхом балансування амінокислотного складу. Важлива роль відводиться мікробіологічному синтезу, за допомогою якого одержують амінокислоти для різних потреб. Амінокислоти та їхні суміші широко застосовують у тваринництві (вони збагачують рослинні корми лізином, метіоніном, треоніном, триптофаном), як харчові добавки при виробництві харчових продуктів, як спеції (глутамінова кислота формі натрієвої солі), а також як вихідні продукти в синтезі поліамідів, барвників, синтетичних волокон.

Окремі амінокислоти використовують у медицині для лікування різних хвороб (Petrikov et al., 2010).

3 розвитком нанотехнологій амінокислоти стали застосовувати як компоненти наноліків, а також для формування та зниження токсичності наноматеріалів, які використовують в наномедицині (Chekman, 2009; Chekman et al., 2014).

Амінокислоти займають центральне місце в обміні нітрогеновмісних сполук, входять до складу білків, пептидів, беруть участь у синтезі пуринів, піримідинів, вітамінів. У процесі еволюційного пристосування до життєдіяльності у відповідних екологічних умовах виробилась специфіка взаємодії різних за фізіологічними і біохімічними особливостями видів мікроорганізмів з речовинами зовнішнього середовища. Упродовж мільярдів років відповідні види мікроорганізмів синтезують органічну речовину, використовуючи енергію окиснення амоніаку, $\mathrm{NH}_{3}$ (утворюється при гнитті решток рослин і тварин) та нітритів $\left(\mathrm{NO}_{2}^{-}\right)$для асиміляції вуглекислоти та інших ендергонічних процесів, а тому відіграють важливу роль у кругообігу

$$
\mathrm{HNO}_{2} \rightleftarrows \mathrm{H}^{+}+\mathrm{NO}_{2}^{-}
$$

нітрогену в природі. Біосинтез амінокислот здійснюється через реакції ферментативного відновлювального амінування<smiles>[R]C(=O)C(=O)O</smiles>

або переамінування<smiles>[R]C(=O)C(=O)O</smiles><smiles>[R]C(N)C(=O)O</smiles>

Продуцентами, які засвоюють $\mathrm{NH}_{3}, \mathrm{NO}_{2}^{-}, \epsilon$ анаеробні гетеротрофні прокаріоти-хемосинтетики, які й сьогодні розповсюджені у грунтах та водоймах. Це високоспеціалізовані бактерії-нітрифікатори родів Nitrosomonas, Nitrosobacter, Nitrosospira, Nitrosococcus, Nitrosolobus.

Одержання мікробних метаболітів, включно з амінокислотами, має важливе значення в хімічній технології. Завдяки масштабному вирощуванню мікроорганізмів в промислових умовах отримують амінокислоти, білки, препарати для підвищення продуктивності<smiles>[R]C(=O)C(=O)O</smiles>

сільськогосподарських культур. Отримано мікробні препарати, які ефективно застосовують при боротьбі iз захворюваннями тварин (Shaposhnikova et al., 2012).

Мікроорганізми для побудови речовин свого тіла використовують найпростіші сполуки. Вони синтезують практично всі амінокислоти, які є в природі. Інтерес до мікробіологічного синтезу амінокислот пояснюється постійним збільшенням випуску мікробних препаратів. Головною перевагою мікробного біосинтезу над хімічним $є$ те, що мікроорганізми продуку- 
ють біологічно активні L-ізомери (Bezborodov, 1969; Sasson, 1987).

Потреби різних галузей промисловості вимагають інтенсифікації виробництва амінокислот, вдосконалення існуючих і впровадження нових технологій, пошуків дешевих субстратів та продуктивніших штамів. У мікробіологічній промисловості використовують здатність мутантних штамів продукувати цільові амінокислоти (глютамінову кислоту, лізин). Висхідними для промислових процесів $\epsilon$ мікробні штами 3 порушеною регуляцією синтезу. Результати досліджень свідчать, що мутагенізований внаслідок зміни ключових генів штам D.sp. IMB B-7447 збільшує накопичення лізину порівняно зі штамом D.sp. 90 (Andriiash et al., 2014).

Мікробіологічний синтез амінокислот активують збільшенням утилізації субстрату; підвищенням швидкості утворення і активності ферментів біосинтезу амінокислот; стимуляцією виділення продукту в позаклітинне середовище; стимуляцією попередників цільових амінокислот.

Регулювати та інтенсифікувати шляхи біосинтезу амінокислот можна внесенням до середовища відповідних сполук (Andriiash et al., 2012).

Поширеними об'єктами селекції продуцентів амінокислот є бактерії роду Corynobacterium, які мало піддаються фаголізису, мають цінні властивості, прості шляхи синтезу сполук. При рості C.glutamaticum у середовищі 3 меншою за оптимальну концентрацією біотину порушується синтез мембранних ліпідів і глутамат натрію виходить з клітин та накопичується у середовищі. Тому при синтезі L-лізину на мелясі у середовище додають біотин для захисту від продукування L-глютамінової кислоти (побічний продукт), або мінімальні концентрації гомосерину (або суміші метіоніну і треоніну), які стимулюють ріст. L-треонін застосовують як субстрат при одержанні Lізолейцину за участю штаму Serratia marscens. При цьому L-треоніндезаміназа каталізує конверсію у $\alpha$ кетомасляну кислоту i амоніак та індукує синтез. Метаболічним прекурсором у синтезі триптофану є антранілова кислота, відносно недорога, ії легко можна синтезувати хімічним методом із фталевого ангідриду (Sasson, 1987).

Мікробний ріст практично завжди лімітований за поживним компонентом, а достатня концентрація основних поживних речовин активує синтетичну діяльність мікроорганізмів. Ріст мікробних клітин обмежує нестача основних елементів живлення у середовищі - карбону, нітрогену, сульфуру. Різні бактерії для синтезу амінокислот використовують також азот, нітрати, сечовину. Дефіцит сульфуру лімітує утилізацію нітрогену, тому сульфуровмісні сполуки, навпаки, стимулюють біосинтез в цілому, зокрема сульфуровмісних амінокислот - метіоніну, цистеїну і цистину (Bezborodov, 1969; Whanger et al., 1978). Для синтезу білка важливим є співвідношення сульфуру до нітрогену: сульфуру повинно бути в 10 разів менше (Nishchemenko et al., 2014).

Температура, як і компонентний склад середовища - важливий фактор, який впливає на мікробний синтез, накопичення метаболітів у субстраті. Температу- рний оптимум $\left(25-35^{\circ} \mathrm{C}\right)$ забезпечує активний ріст $\mathrm{i}$ розмноження мікроорганізмів, що стимулює синтез різних метаболітів. Активна азотфіксація у бобових рослин протікає при температурі грунту $24-26{ }^{\circ} \mathrm{C}$ (Kyrylenko, 2013).

Конкуренція щодо експлуатації запасів викопної сировини сприяє застосуванню процесів нового типу при виробництві хімічних речовин з відновлювальної біомаси, багатої амінокислотами, білками і мікроелементами. Користь можна одержати від мікроорганізмів при розкладанні відходів і побічних продуктів діяльності в галузі сільського господарства, лісової і харчової промисловості (Hromyko \& Pashkov, 2015).

При вирощуванні енергетичних культур для виробництва біопалива виснажуються грунти і залишаються неутилізовані органічні рештки (гумус, рослинні рештки, відходи агропромислового комплексу). Перспективними біотехнологічними об'єктами в останні десятиріччя стали дикорослі та культивовані макроміцети, які завдяки специфічним метаболітам мають широкий діапазон застосувань. Базидіальні міксоміцети використовують готові органічні сполуки в процесі біодеструкції лігнінцелюлозних комплексів. При вирощуванні на агаризованих середовищах 3 водних екстрактів таких біосубстратів швидкість росту штамів була максимальною у випадку сорго i перевищувала швидкість росту штамів на контрольному середовищі ( 8 Б 2013).

У результаті проведених раніше нами досліджень 3 інкубування біосубстрату протягом 3 діб при температурі $18{ }^{\circ} \mathrm{C}$ встановлено, що мікробна асоціація підвищує синтез біологічно активних сполук. Загальний вміст амінокислот зріс з 22, 69 до 24,74 мг/г натуральної речовини. При цьому відмічено зростання кількості треоніну, серину,глютамінової та аспарагінової кислоти, гліцину, валіну, метіоніну, лейцину, ізолейцину, тирозину, триптофану, гістидину, лізину. Вміст аргініну не змінився, а проліну - дещо зменшився. Кращий стимулюючий вплив на синтез амінокислот виявив додатково внесений сульфат натрію (0,3\% від маси біосубстрату). Інкубування із сульфатом натрію протягом 3 діб при температурі $25^{\circ} \mathrm{C}$ сприяло зростанню загального вмісту амінокислот до 25,16 мг/г субстрату. Виявлено незначне зменшення вмісту треоніну, валіну, лейцину, гістидину, аргініну. Згодовування такого біосубстрату курям як кормової добавки до основного раціону стимулювало їх ріст та розвиток, підвищило якість продукції і продуктивність (Gvozd', 1992).

Проведено дослідження зі стимулювання життєдіяльності симбіотичної мікробної асоціації біосубстрату шляхом інкубації при 25 та $27{ }^{\circ} \mathrm{C}$ зі сульфатом натрію та меласою (побічним продуктом при одержанні цукру, який містить, крім цукру, сульфіти, карбонати, солі кальцію, магнію). Відмічено зростання вмісту біологічно активних речовин, в тому числі амінокислот в біосубстраті, який може бути використаний для кормових добавок та препаратів для корекції обміну речовин сільськогосподарських тварин і птиці, підвищення продуктивності та якості продукції (Kravtsiv \& Korytko, 2004). 
Отриманий нами біосубстрат застосовано для компостування у поєднанні 3 осадом стічних вод (OCB) і використано як добриво. Виявлено його позитивний вплив на розвиток кореневої системи рослин (ріпаку, кукурудзи), ріст і розвиток та врожайність. Інші автори повідомляють про доцільність використання біокомпосту як екологічно ефективного чинника при меліорації грунтів (Manivchuk, 2003).

Активна роль у процесах біотрансформації речовин належить мікроорганізмам травного тракту, які перебувають у симбіозі 3 організмом тваринигосподаря, забезпечують його амінокислотами та іншими біологічно активними сполуками і енергією. Особливо складні процеси протікають у рубці жуйних, симбіотична мікрофлора якого включає велику кількість різноманітних бактерій, найпростіших. За їх участі у рубці розкладаються багаті на клітковину та лігнін рослинні корми, які є основою у живленні жуйних. При цьому утворюється ацетат і пропіонат важливе джерело енергії. Склад раціону впливає на кількість мікроорганізмів окремих видів і їх метаболічну активність у рубці (Tarakanov, 2001). Амінокислоти, що утворюються в рубці, засвоюються бактеріями, а також всмоктуються в кров і далі перетворюються в сечовину (Nishchemenko et al., 2014).

Мікробна деградація непротеїнового нітрогену i його інкорпорація у мікробний білок становить предмет вивчення. Мікроорганізми-симбіонти для синтезу амінокислот і власного білка використовують аміак, який утворюється в рубці при розпаді білка корму (Whanger et al., 1978).

Вирішення проблеми скорочення дефіциту білка залежить від збільшення виробництва кормового білка, поліпшення його якості та раціонального використання корму. Це своєю чергою тісно пов'язане з використанням різних кормових добавок рослинного, тваринного та мікробного походження 3 високим вмістом білка і незамінних амінокислот. Рослинні корми, крім бобових, бідні на незамінні амінокислоти. Тому важливе значення має доповнення кормових раціонів дефіцитними амінокислотами, насамперед лізином, метіоніном, триптофаном, які необхідні для синтезу білків в організмі в достатній кількості та у відповідних співвідношеннях. Незбалансованість раціону хоча б за однією амінокислотою лімітує використання всіх інших амінокислот для синтезу протеїну (Nikonov, 2012; Ibatullin et al., 2014). Кількість мікроорганізмів у вмісті рубця та їх ензиматична активність зростає під впливом сульфуровмісних амінокислот (Tarakanov, 2003).

Ефективне використання білків корму можливе за відповідності співвідношення найбільш дефіцитних амінокислот потребам тварин. Останні інстинктивно надають перевагу раціону, збалансованому за амінокислотами. Досягають оптимальне співвідношення амінокислот комбінацією природних кормових джерел азоту або додаванням до раціону дефіцитних амінокислот промислового виробництва. Актуальними є препарати 3 використанням ефективних мікроорганізмів (ЕМ), які впливають на ферментативні процеси під час силосування корму, збагачують його амінокислотами. Це велика група співіснуючих разом корис- них аеробних та анаеробних мікроорганізмів, що включає 80 їх видів, до якої належать молочнокислі бактерії, дріжджі, актиноміцети та інші. У результаті ферментації ячмінного шроту з ЕМ-препаратом протягом 6 днів при температурі $25{ }^{\circ} \mathrm{C}$ виявлено зміну співвідношення амінокислот у ферментованому кормі. Пул вільних амінокислот містив більшу кількість лізину, валіну, метіоніну, лейцину, ізолейцину тирозину та фенілаланіну порівняно $з$ контролем при зменшенні вмісту гістидину, цистину, глютамінової та аспарагінової кислот (Zinoviev, 2002).

Амінокислоти як засоби захисту рослин мають широке застосування. Препарати, що містять амінокислоти, забезпечують їхнє включення у метаболізм рослини зі збереженням енергії, необхідної на продукування цих метаболітів, та накопичення азоту. Комплекс амінокислот з мікроорганізмами сприяє зменшенню ураження рослин бактеріозом. Застосування препаратів, які містять метіонін, підвищує стійкість злаків до вилягання і дії патогенних бактерій. Важлива роль належить гліцину та проліну. Гліцин впливає на утворення халатних комплексів, як прекурсор хлорофілу збільшує ефективність фотосинтезу. Пролін поліпшує розвиток рослин, врожайність, стабілізує структуру і синтез білків, протидіє водному стресу (Golovnev et al., 2004; Avhustovych, 2018).

В організмі тварин більшість замінних амінокислот синтезується зі звичайних безазотових продуктів обміну і амонійного нітрогену (незамінні амінокислоти поступають у складі дієти). Вищі рослини всі необхідні амінокислоти синтезують з амонійних солей, нітратів і нітритів. Нітроген, засвоєний рослинами для синтезу амінокислот та білків, далі по трофічних ланцюгах потрапляє в організм тварин та людей.

Деструктивний антропогенний вплив на довкілля підміняє собою біогенну еволюцію, темпи якої диктує не хід природних явищ, а трансформовані природні екосистеми - одноманітні за біогеохімічними характеристиками агросистеми. Несприятливий розвиток екологічної ситуації і як наслідок - тотальне зниження родючості грунту за останні десятиріччя на планеті, в усіх зонах України в т. ч., вимагає збалансування. Необхідна зміна пріоритетів, яка повинна спрямовуватись на використання в системах удобрення, крім традиційного органічного добрива - підстилкового гною, - вторинної продукції рослинництва - соломи і сидератів і оптимальних доз мінеральних добрив (Yermolaiev \& Khokhlov, 2013).

Родючість грунту - одна 3 найважливіших його властивостей. Грунт забезпечує рослини поживними елементами, від чого залежить їх ефективне вирощування для одержання продуктів харчування і сировини для промисловості (Sedilo et al., 2018). Заходи 3 відтворення грунтової родючості насамперед залежать від мікробіологічних процесів деструкції-синтезу гумусових речовин. Грунтові мікроорганізми відіграють важливу роль у грунті, розкладають органічну речовину і переводять в неорганічну (Volkohon, 2013). Органічні речовини грунту, включно з амінокислотами та білками, легко переробляються мікроорганізмами і швидко зникають. Сульфурвмісні органічні речовини грунту включають амінокислоти цистеїн, цистин 
і метіонін, а також вітаміни тіамін і біотин. Вивільнення мінеральних речовин 3 органічного матеріалу відбувається поволі, забезпечуючи рослини безперервним джерелом живлення (Barber, 1988).

У бобових рослин бульбочки коренів заселені азотфіксуючими бактеріями, які засвоюють атмосферний азот, перетворюють в амоній $\left(\mathrm{NH}_{4}^{+}\right)$і використовують для синтезу амінокислот та білків. Розвиток уявлень про азотфіксуючі симбіотичні асоціації дав можливість для використання їх потенціалу у сільському господарстві, зокрема для інокуляції бобових, а розуміння механізмів, які регулюють нітрогенкіназу, дозволило оптимізувати застосування добрив (азотових, сульфурвмісних). Відкрились можливості азотфіксуючих симбіотичних асоціацій для створення ценозів 3 бобовими і небобовими рослинами (Marschner et al., 2004). Дослідження біологічної фіксації атмосферного азоту, створення нових азотфіксуючих симбіотичних асоціацій попри існуючі між бобовими рослинами i бактеріями роду Rhizobium дають можливість підвищувати продуктивність рослин.

Для підвищення симбіотичної азотфіксації і продуктивності бобових культур найефективнішим прийомом $\epsilon$ інокуляція препаратів бульбочкових бактерій. Передпосівна обробка насіння штамами Rhizobium galegae активізує засвоєння молекулярного азоту та підвищує врожайність і якість зеленої маси рослин козлятнику (Kyrylenko, 2013; Kyrylenko et al., 2014). Інокуляція активним штамом азоспірил, Azospirillum brasilense 10/1 може бути ефективним засобом підвищення рівня фіксації молекулярного азоту в кореневій зоні тритикале ярого, дозволяє підвищити азотфіксуючий потенціал рослин (Patyka et al., 2015).

В останні роки популярності набули генетично модифіковані рослини, зокрема соя. Тому важливим є вивчення впливу генетично модифікованих рослин на розвиток ризосферної мікробіоти, від якої залежить спрямованість та інтенсивність кругообігу речовин, зокрема азотфіксація. Дослідженнями встановлено залежність структури мікробної асоціації ризосфери генетично модифікованої сої від кліматичних умов та пестицидного фону за вегетаційний період. Виявлено високу чутливість олігоазототрофних та целюлозолітичних мікроорганізмів до факторів середовища, тимчасом як кількість мікроорганізмів роду Azotobacter не змінюваласть (Brovko et al., 2013).

У рослин амінокислоти є не лише складовими білків, вони ще й стимулюють проростання насіння, регулюють інтенсивність фотосинтезу, розвитку i росту, кущення і врожайність, процес акліматизації. Під дією стрес-факторів (УФВ, пестициди, важкі метали, промислове забруднення) в рослинах активуються захисні механізми, які включають продукування відповідальних за імунітет сполук - амінокислот і білків, що захищають від незворотних змін структуру та функції рослин, від порушення метаболізму азоту (Avhustovych, 2018).

Вважають, що активація біосинтезу деяких амінокислот внаслідок обробки метанолом підвищує посухостійкість рослин і врожайність в умовах водного дефіциту. Степанов С.C., Золотарьова О.К. (Stepanov \& Zolotarova, 2013) встановили, що при цьому в клі- тинах Chlamidomonas reinchardtii зростає внутрішньоклітинний вміст NAD(P), водорозчинних протеїнів, вільних амінокислот, зокрема треоніну (прекурcop у біосинтезі ізолейцину) і тирозину, при одночасному зменшенні метіоніну внаслідок ймовірного включення його у синтез білків. Ці дані можуть свідчити про активацію асиміляції азоту клітинами у формі нітрату

Промислове виробництво амінокислот, особливо метіоніну та лізину, триптофану розвивається не тільки для харчування людей та одержання добавок до комбікорму худоби, а й для інших потреб. Вважливим $\epsilon$ впровадження нових технологій, більш продуктивних штамів, пошук економічно вигідних субстратів. За допомогою мікроорганізмів можна розкладати побічні продукти сільського господарства, відходи виробничих підприємств для одержання біомаси, багатої білками, виготовлення біодобрив для підвищення родючості грунту, що сприяє, крім того, очищенню довкілля і поліпшеню екологічної ситуації.

\section{Висновки}

В останні десятиріччя мікроорганізми й надалі $є$ перспективними біотехнологічними об'єктами. Інтерес до мікробіологічного синтезу пояснюється постійним збільшенням попиту на мікробні препарати, на різні амінокислоти, багату білками мікробну біомасу. Мікроорганізми синтезують практично всі амінокислоти, які є в природі, причому тільки біологічно активні L-ізомери, для доповнення кормових раціонів за дефіцитними амінокислотами 3 метою задоволення потреб тварин і для інших потреб.

За допомогою мікроорганізмів можна розкладати відходи і побічні продукти діяльності в галузі сільського господарства, лісової і харчової промисловості, лісового господарства для одержання біомаси, багатої білками, а також для виготовлення біодобрив, внесення яких у грунт підвищує його родючість.

Використання природної сировини в біотехнологічних процесах дає можливість отримати біосубстрати, збагачені амінокислотами. При інкубуванні біосубстрату на основі торфу в ньому зростає загальна кількість амінокислот під впливом температури та сульфату натрію. Використаний як добавка до раціону курей біосубстрат підвищує продуктивність і покращує якість продукції.

Перспективними $є$ бактеріальні препарати, які вносять у грунт 3 метою поліпшення ефективності мікробних угруповань, в тому числі амоніфікаторів, що підвищує врожайність культур, а також препарати, які застосовують під час ферментації кормів. Мікроорганізми, синтезуючи органічні сполуки, включно 3 амінокислотами, забезпечують ними організм господаря.

Наведені дані сприяють кращому розумінню ролі амінокислот, шляхів підвищення їх вмісту в різних біологічних об'єктах з метою збільшення вмісту протеїну в сільськогосподарській продукції і поліпшення iï якості, а також підвищення родючості грунту, що є ключовим питанням сьогодення. 


\section{References}

Andriiash, G.S., Zabolotna, G.M., \& Shulga, S.M. (2012). Regulation and intensification ways of lysine biosynthesis. Microbiologiitato biotechnologiia, 4, 6-17. doi: 10.18524/2307-4663.2012.4(20).90435.

Andriiash, H.S., Zabolotna, H.M, \& Bondarenko, V.S. (2014). Filohenetychnyi analiz shtamiv - produtsentiv lizynu porivnianniam poslidovnosti hena $16 \mathrm{SrRNK}$ Biotechnologia Acta: specific journal, 6, 40-45. http://biotechnology.kiev.ua/index.php?option=com_c ontent\&view $=$ article $\&$ id $=560 \% 3 \mathrm{~A}-16 \mathrm{~s}-1-1-2$ \&catid=94\%3A2014-6\&Itemid $=119 \&$ lang $=u k \quad$ (in Ukrainian).

Avhustovych, M. (2018). Aminokysloty: mif chy realnist. Propozytsiia: ukrainskyi zhurnal z pytan ahrobiz-nesu, 12, 104-107 (in Ukrainian).

Barber, S.A. (1988). Biologicheskaja dostupnost' pitatel'nyh veshhestv v pochve. M.: "Agropromizdat" (in Russian).

Bezborodov, A.M. (1969). Biosintez biologicheski aktivnih veshhestv mikroorganizmami. L.: Medicina (in Russian).

Brovko, I.S., Leonova, N.O., \& Titova, L.V. (2013). Formirovanie mikrobnogo soobshhestva kornevoj zony gli-fosattolerantnoj soi. Tezy dopovidei KhIII zizdu tovarystva mikrobiolohiv Ukrainy im.S.M. Vynohradskoho, 1-6 zhovtnia 2013. Sim-feoropol: VD “Arial”, 29 (in Russian).

Chekman, I.S. (2009). Nanoscience prospect of scientific investigations. Nauka ta innovatiia, 5(3), 89-93 (in Ukrainian).

Chekman, I.S., Horchakova, N.O., Syrova, H.O., Kazakova, O.A., Nahorna, T.I., \& Shatorna, V.F. (2014). Zastosuvannia aminokyslot dlia stvorennia nanostruktur. Biotechnologia Acta: specific journal, 6, 83-91. https://cyberleninka.ru/article/n/zastosuvannyaaminokislot-dlya-stvorennya-nanostruktur Ukrainian).

Golovnev, N.N., Vasiliev, A.D., Molokeev, M.S., Novikova, G.V., \& Sergeeva, M.V. (2004). Synthesis of the metals with beta-alanine complex compounds. Bulleten Kharkovskogo gos.un-ta, 2, 14-20 (in Russian).

Gvozd', O.O. (1992). Izmenenie soderzhanija vitaminov V1 i V12 i aminokislot v processe biotehnologicheskoj obrabotki torfa s primeneniem sul'fata natrija i ih vlijanie na nekotorye biohimicheskie pokzateli i produktivnost' cypljat-brojlerov. Avtoreferat dis... kand. biolog. nauk. L'vov (in Russian).

Hrodzynska, H.A., Lomberh, M.L., Myroliubov, O.V., Bilai, V.H., Zaimenko, M.V., Rakhmetov, D.B. (2013). Biotrans-formatsiia vidkhodiv enerhetychnykh roslyn bazydialnymy hrybamy. Tezy dopovidei KhIII zizdu tovarystva mikro-biolohiv Ukrainy im. S.M. Vynohradskoho, 1-6 zhovtnia 2013. Simfeoropol: VD "Arial”, 34 (in Ukrainian).

Hromyko, M.H., \& Pashkov, A.P. (2015). Svitovi ekoloho-ekonomichni prioritety u vyrishenni problem vidchodiv. Bezpeka zhyttiediialnosti, 19-22 (in Ukrainian).
Ibatullin, I.I., Kryvenok, M.Ia., \& Ilchuk, I.I. (2014). Teoretychne ta eksperymentalne obgruntuvannia zminy potreb kurei batkivskoho stada $\mathrm{u}$ treonini ta metionini zalezhno vid viku ta produktyvnosti. Suchasne ptakhivnytstvo: naukovo-vyrobnychyi zhurnal, 2, 4-7 (in Ukrainian).

Kravtsiv, R.I., \& Korytko, O.O. (2004). Sposib stymuliatsii syntezu biolohichno aktyvnykh rechovyn symbiotychnoiu mikrobnoiu asotsiatsiieiu $\mathrm{v}$ torfi. Deklaratsiinyi patent na vynakhid N 67119. Opublikovano: 15.06.2004. http://uapatents.com/467119-sposib-stimulyaci-sintezu-biologichnoaktivnikh-rechovin-simbiotichnoyu-mikrobnoyuasociaciehyu-v-torfi.html (in Ukrainian).

Kyrylenko, L.V. (2013). Vplyv faktoriv na protsesy biolohichnoi azotfiksatsii. Tezy dopovidei KhIII zizdu tovarystva mikrobiolohiv Ukrainy im. S.M. Vynohradskoho, 1-6 zhovtnia 2013. Simfeoropol: VD "Arial”, 42 (in Ukrainian).

Kyrylenko, L.V., Shkatula, Yu.M., Kots, Ya.S., Mamenko, P.M., \& Patyka, V.P. (2014). Formuvannia vysokoefektyvnoi symbiotychnoi systemy Rhizobium galegae - kozliatnyk. Visnyk ahrarnoi nauky, 1, 2225. http://nbuv.gov.ua/UJRN/vaan_2014_1_6 (in Ukrainian)

Manivchuk, Yu.V. (2003). Ekolohichno efektyvna systema biomelioratsii hirskych hruntiv Karpat za dopomohoiu biokompostiv. Naukovyi visnyk Uzhhorodskoho universytetu. Ser. Biolohiia, 13, 92-95 (in Ukrainian).

Marschner, P., Crowley, D.E., \& Yang, C.H. (2004). Development of specific rhizosphere bacterial communities in relation to plant species, nutrition and soil tipe. Plant and soil, 261(1-2), 199-208. https://link.springer.com/article/10.1023/B:PLSO.000 0035569.80747.c5.

Nikonov, I.N. (2012). Aminokislotnyj sostav kombikormov i mikroflora kishechnika kur-nesushok. Zootehnija: teore-ticheskij y nauchno-prakticheskij zhurnal, 11, 2728. http://naukarus.com/aminokislotnyy-sostavkombikormov-i-mikroflora-kishechnika-kur-nesushek (in Russian).

Nishchemenko, V.O., Shtepenko, A.P., \& Chub, O.B. (2014). Vplyv sirkovmisnykh aminokyslot na pokaznyky rubtsevoho travlennia molodniaku velykoi rohatoi khudoby. Naukovyi visnyk Lvivskoho natsionalnoho universytetu vete-rynarnoi medytsyny ta biotekhnolohii im. S.Z. Hzhytskoho, 12, 2(44), 219-222. http://nbuv.gov.ua/UJRN/nvlnu_2010_12_2\%282\%29 40 (in Ukrainian).

Patyka, V.P., Nadkernychna, O.V., \& Shakhovnina, O.O. (2015). Vplyv Azospirillum brasilense 10/1 na asotsiatyvnu azotfiksatsiiu i vnutrishno-sortovyi polimorfizm trytykale yaroho. Mikrobiolohichnyi zhurnal, 77(5), 29-36. http://nbuv.gov.ua/UJRN/ MicroBiol_2015_77_5_5 (in Ukrainian).

Sasson, A. (1987). Biotehnologija: svershenija i nadezhdy. M.: "Mir", 169-195 (in Russian).

Sedilo, H.M., Dubytska, A.O., Kachmar, O.I., Vavrynovych, O.V., \& Dubytskyi, O.L. (2018). Rodiuchist gruntu pid pshenytseiu ozymoiu za ekolohichno bezpechnykh system udobrennia. Visnyk 
ahrarnoi nauky, 12(789), 19-25. http://agrovisnyk.com/pdf/ua_2018_12_03.pdf (in Ukrainian).

Shaposhnikova, M.Ju., Vasil"ev, P.G., \& Shhelgachev, V.V. (2012). Vlijanie kompleksov BAV, poluchennyh iz fugatov glubinnyh kul'tur V.licheniformis i V.sublitis na sostojanie zdorov'ja i prirost massy otkormochnogo molodnjaka svinej v period vspyshki zheludochno-kishechnyh zabolevanij neustanovlennoj jetiologii. Zh. Veterinarnyj vrach, 3, 15-19 (in Russian).

Stepanov, S.S., \& Zolotarova, O.K. (2013). Vplyv metanolu na vmist $\mathrm{NAD}(\mathrm{P})$, vilnykh aminokyslot $\mathrm{i}$ proteinu v klitynakh Chlamidomonas reindchardtii. Ukrainskyi biokhimichnyi zhurnal, 4, 82-89. http://ukrbiochemjournal.org/wp-content/uploads/ 2015/10/Stepanov_4_13.pdf (in Ukrainian).

Tarakanov, B.V. (2001). O tipah brozhenija v rubce zhvachnyh. Zootehnija, 6, 8-9 (in Russian).

Tarakanov, B.V. (2003). Vlijanie aminokislot na fermentativnuju aktivnost' mikroflory rubca. Zootehnija, 6, 11-13 (in Russian).

Volkohon, V.V. (2013). Biolohichni aspekty formuvannia rodiuchosti gruntiv. Tezy dopovidei KhIII zizdu tovary-stva mikrobiolohiv Ukrainy im. S.M. Vynohradskoho, 1-6 zhovtnia 2013. Simfeoropol: VD "Arial”, 40 (in Ukrainian).

Whanger, P.D., Weswig, P.H., \& Oldfield, J.F. (1978). Selenium, Sulfur and Nitrogen levels in ovine rumen microorganisms. Jornal of Animal Sciens, 46(2), 515519. doi: $10.2527 /$ jas $1978.462515 x$.

Yermolaiev, M.M., \& Khokhlov, V.V. (2013). Zminy humusnoho stanu dernovo-pidzolystoho gruntu pid vplyvom udo-brennia u sivozminakh polissia. Visnyk ahrarnoi nauky, 1, 11-14. http://nbuv.gov.ua/UJRN/ vaan_2013_1_4 (in Ukrainian).

Zinoviev, S.H. (2002). Vyvchennia vplyvu efektyvnykh mikroorhanizmiv na kilkisne spivvidnoshennia aminokyslot u kormakh. Visnyk Poltavskoi derzhavnoi ahrarnoi akademii. Poltava, 5/6, 105-107 (in Ukrainian).

Petrikov, S., Zinkin, V.Y., Solodov, A.A., Roar, A.A., \& Krylov, V.V. (2010). Use of enteral glutamine in the structure of artificial feeding in patients with intracranial hemorrhages. Bulleten intensivnoi terapii, 4, 5964 (in Russian). 